УДК 340

Юрій Володимирович Почепцов, аспірант Інституту держави і права ім. В. М. Корецького НАН України

\title{
ФАКТОРИ ДІЄВОСТІ ТА ЕФЕКТИВНОСТІ ПРАВА ЯК УМОВА ЙОГО ФУНКЦІОНУВАННЯ
}

Постановка проблеми. Питання ефективності і дієвості права $є$ одними з найактуальніших як в науковому, так і в практичному плані, що не дивно з огляду на постійний розвиток суспільних відносин та необхідність удосконалення їх нормативно-правового забезпечення у спосіб, який задовольнятиме потреби суспільства, відповідатиме вимогам часу та міжнародним стандартам. Водночас, їх вивчення у напрямку винайдення шляхів оптимізації механізмів правового регулювання має здійснюватись на базі повноцінного виявлення та аналізу факторів дієвості та ефективності права, що $є$ одною з ключових умов його функціонування. Вказана проблематика в юридичній літературі розкрита досить епізодично та непослідовно, що зумовлює відсутність цілісного уявлення про заявлену проблематику. Водночас їх наукова розробка $\epsilon$ актуальною, визначена практикою функціонування права, тими недоліками, котрі викликані недостатністю його ефективності та дієвості.

Аналіз останніх досліджень та публікацій. На рівні наукових досліджень окремі питання факторів дієвості та ефективності права вивчаються вченими-правознавцями, починаючи з XIX ст. і до сьогодні. Особливо грунтовними $є$ ідеї таких вітчизняних та зарубіжних вчених, як С. С. Алексєєв, М. Р. Аракелян, А. Б. Венгеров, В. В. Глазирін, А. Я. Гуревич, С. О. Жинкін, В. В. Завальнюк, І. О. Ільїн, В. П. Казимирчук, Д. А. Керімов, Б. О. Кістяківський, М. М. Ковалевський, М. В. Колесник, М. М. Коркунов, В. В. Лапаєва, М. П. Лєбєдєв, О. В. Малько, С. А. Муромцев, П. І. Новгородцев, Н. Р. Нугаєва, Н. М. Оніщенко, Л. Й. Петражицький, С. І. Пунченко, П. М. Рабінович, Г. В. Рибікова, І. С. Самощенко, Т. І. Тарахонич, Л. С. Явич та ін. Однак, й досі для окресленої проблематики властивий плюралізм наукових підходів з більшості питань, тоді як окремі з них, навпаки, залишаються недостатньо дослідженими і висвітленими у наукових працях. Зокрема, відсутні системні правові дослідження ефективності і дієвості права, в тому числі і крізь призму факторів, що їх визначають.

Мета дослідження. Виходячи з теми цієї наукової роботи, іiі метою є: на підставі аналізу доктринальних підходів до розуміння факторів ефективності та дієвості права визначити особливості регламентаційного впливу права на суспільні відносини, встановити та узагальнити вказані фактори, уточнити їх характеристики.

Методи та процедури дослідження. Методологію дослідження складають загальнонаукові і спеціально-наукові методи наукового пізнання, зокрема історико-правовий та системно-структурний, за допомогою яких опрацьовувалась джерельна база дослідження, вивчались наукові концепції, поняття і категорії, формулювались пропозиції, рекомендації та інші висновки.

Основні результати дослідження. Насамперед важливо здійснити аналіз доктринальних підходів до розуміння факторів, котрі визначають дієвість та ефективність права. На переконання А. В. Корнєва, фактори ефективності права являють собою сукупність реально існуючих загальносоціальних та юридичних умов, що чинять вплив на створення правових норм, їх реалізацію, а також кількісно-якісні зміни соціальної дійсності, які виступають наслідком реалізації правових приписів. Юридичні фактори ефективності нормативно-правового акта вчений визначає, як сукупність вимог, яким має відповідати цей акт, щоб найбільш повно реалізувати регулятивний потенціал права [1, с. 127]. На нашу думку, з огляду на існуючі підходи до виділення різновидів цих факторів, вважаємо, що такий підхід $є$ універсальним і на його основі можна в цілому відобразити головну сутність факторів ефективності права - це сукупність умов, дотримання яких дозволяє праву діяти ефективно. Звичайно таку дефініцію можна і надалі конкретизувати із виділенням етапів «руху» права, за допомогою перерахування основних класифікаційних груп цих факторів, а також називаючи різноманітні наслідки дії права. Однак, ці кроки, на нашу думку, сприятимуть лише деталі- 
зації дефініції, в тому числі за рахунок конкретизації і деталізації елементів ефективності права, адже її сутність від цього не зміниться.

Водночас, маємо відзначити, що у наукових джерелах фактори ефективності права часто позначаються за допомогою таких термінів, як «фактори», «чинники», «умови», «передумови». Інакше кажучи, єдності серед вчених щодо того, за допомогою якого поняття їх позначати, немає. 3 цього приводу С. О. Жинкін висловився, що використання терміна «передумови»є більш доцільним, оскільки дозволяє уникнути плутанини, хоча, як на нас, таке твердження є дискусійним, тому для його підтримки або спростування пропонуємо звернутись до тлумачного словника української мови. Згідно з ним під словом «передумови» слід розуміти попередні умови існування, виникнення, діяння чого-небудь [2, с. 909]. В свою чергу слово «фактори» позначає умови, рушійні сили будьякого процесу, явища; чинники $[2,1526]$. В свою чергу «чинники» являють собою умови, рушійні сили, причини будь-якого процесу, що визначають його характер або одну з основних рис; фактори [2, с. 1601]. I, нарешті, етимологічне значення слова «умови» полягає в тому, що ним позначаються необхідні обставини, які уможливлюють здійснення, створення, утворення чого-небудь або сприяють чомусь; обставини, особливості реальної дійсності, за яких відбувається або здійснюється що-небудь [2, с. 1506]. Звідси приходимо до висновку, що обрання будь-якого з наведених термінів буде правильним, оскільки ними позначаються однакові явища. Більше того, вважаємо за можливе вживання усіх термінів одночасно або по черзі з метою полегшення формулювання дефініцій чи для уникнення тавтології тощо. Наприклад, П. М. Рабінович розрізняє наступні фактори ефективності (або як їх називає вчений - передумови. - Ю. П.): 1) загальносоціальні, до яких відносить: відповідність норми права об'єктивним законам (закономірностям) існування і розвитку людини та суспільства; відповідність норми конкретно-історичним умовам її функціонування, реальним можливостям iii здійснення (матеріальним, духовним, часовим, кадровим та ін.); 2) спеціально-соціальні (або юридичні), серед яких називає: відповідність норми об'єктивним державно-правовим (юридичним) закономірностям регулювання (наприклад, законам системності, яка несумісна із неузгодженістю, суперечливістю, прогалинністю між структурними елементами кожної правової системи, або ж суперечливістю обов'язковим зв' язкам між структурними елементами кожної юридичної норми чи залежностям між процедурно-процесуальними та матеріальними нормами) тощо [3, с. 173-174].

Натомість А. О. Абрамова класифікує фактори (або їх вона називає ще умовами. - Ю. П.) на: 1) внутрішні, які, у свою чергу, поділяє на загальні і спеціальні, що тотожні критеріям ефективності та мають значення або в цілому для механізму правового регулювання, або для його окремих стадій; 2) зовнішні, які слугують виразом загальних умов ефективності механізму правового регулювання та включають: рівень суспільної правосвідомості, правової культури, ступінь правового інформування громадян, процесів політичного, економічного, суспільного життя, рівень законності, правопорядку, успіх діяльності державних систем та інші фактори середовища, зовнішні по відношенню до механізму правового регулювання [4, с. 7]. Більш широко характеризує фактори ефективності А. М. Миронов, який пропонує застосовувати одразу низку критеріїв для їх всебічного врахування і класифікації (хоча й обмежує вивчення факторів ефективності одним 3 джерел права - нормативно-правовим актом). Так, вчений пропонує вирізняти:

- за видами юридичної діяльності (або етапами дії права): фактори, які відносяться до процесу правотворчості; фактори, що випливають з особливостей процесу право реалізації; фактори, що відносяться до особливостей правосвідомості та поведінки громадян, які дотримуються або порушують вимоги правових норм;

- за сферою дії (впливу) факторів: власне юридичні - сукупність вимог до нормативно-правового акта, при дотриманні яких найбільш повно реалізується закладений у нормативно-правовий акт потенціал породжувати певні правові наслідки; неюридичні - об'єктивні та суб'єктивні умови соціального середовища, які чинять вплив на здатність нормативно-правового акта породжувати, змінювати та припиняти правові наслідки, серед яких найбільш важливими автор вважає: фінансове забезпечення реалізації нормативного акта, рівень правосвідомості, правової культури та лобіювання [5].

К. А. Моллнау аналогічну класифікацію доповнював четвертим різновидом - факторами, пов'язаними з політичною організацією та ії діяльністю [6, с. 78]. На нашу думку, політична організація безпосередньо стосується макрорівня, а тому недоцільно ії вирізняти поміж макросоціальних умов. Продовжуючи характеризувати стан наукових розробок у цій сфері, відмітимо й те, що ча- 
сто ці фактори лише перераховуються у наукових працях без належного розкриття їх змісту та ролі у функціонуванні права. Наприклад, згідно з поглядами О. Я. Кархут умовами ефективності права (зауважимо, що у іії праці йде мова про більш конкретні приклади ефективності - ефективність функціонування механізму правового регулювання суспільних відносин у сфері освіти. - Ю. П.) $€$ : досконалість правових норм, що регулюють відносини у певній сфері та їх узгодженість; відсутність прогалин у правовому регулюванні; стабільність законодавства у відповідній сфері; високий рівень правозастосування; високий рівень правосвідомості та правової культури учасників, надійний захист їх суб'єктивних прав і посилення відповідальності за невиконання юридичних обов'язків [7, с. 200-205].

Висновки. У свою чергу, розглянуті підходи наштовхують нас на думку про те, що фактори ефективності права можна вивчати, класифікувати та виражати за допомогою SWOT-аналізу економічного методу діагностики факторів внутрішнього та зовнішнього середовища, які можуть впливати на успіх економічної діяльності, функціонування підприємства на ринку, його конкурентоздатність, доцільність випуску продукції тощо. Він полягає у тому, що необхідно визначити чотири групи чинників, які визначають: сильні і слабкі сторони, які характеризують внутрішні фактори, а також можливості і загрози, які характеризують зовнішні фактори, до яких відносяться політична, екологічна, економічна ситуація у країні, законодавство тощо [8; 9, с. 302; 10, с. 283].

За допомогою його використання можна побудувати модель ефективності права, у якій буде враховано ії внутрішні й зовнішні фактори, поділені на чотири складові:

1) сильні сторони можна представити: можливість заповнити прогалини, виправити недоліки існуючого нормативно-правового регулювання відносин, задовольнити потреби суспільства, попередити свавілля і беззаконня, посилити захист основоположних прав людини, виконати цілі, сформульовані у стратегіях та концепціях розвитку, можливість виконати зобов'язання, взяті на себе Україною у контексті європейської інтеграції, можливість виконати умови, поставлені перед Україною міжнародними організаціями тощо;

2) слабкі сторони: недостатнє фінансове забезпечення реалізації усіх положень нормативного акта; відсутність супутніх підзаконних нормативних актів, якими буде затверджено порядки, переліки, інструкції, про які згадується у нормативному акті; колізії між цим актом та іншим, прийнятим раніше; невідповідність усім вимогам юридичної техніки; не всі проблеми у цій сфері будуть вирішені за допомогою цього акта; його прийняття призведе до необхідності здійснення додаткових фінансових витрат, створення нових органів влади, залучення інших ресурсів; контроль за дотриманням закону ускладнений через відсутність нормативно затвердженого механізму контролю за дотриманням законодавства у цій сфері тощо;

3) можливості: розвиток галузі, яку регулюватиме цей нормативний акт; удосконалення нормативно-правової бази держави; формування нових галузей права; розвиток правової науки; удосконалення юридичної освіти; підвищення правової свідомості і правової культури населення і публічних службовців; удосконалення публічного управління; адаптація законодавства до міжнародних стандартів; підвищення рівня законності у державі; зміцнення верховенства права тощо;

4) загрози: неприйняття населенням або окремими соціальними групами положень цього акта та наслідків його введення; невідповідність очікуваного результату отриманим наслідкам; порушення прав та інтересів громадян; розвиток, зміна суспільних відносин, які становлять предмет правового впливу, що нівелюють актуальність нормативного акта; мітинги, демонстрації громадян проти прийняття нормативного акта, зміни у нормативному регулюванні відносин; зростання незаконної (підпільної. прихованої) діяльності, що заборонена таким нормативним актом; дефіцит бюджету (для забезпечення виконання положень закону у довготривалій перспективі) тощо.

\section{Список використаних джерел}

1. Корнев А. В. Социология права : учебник. Москва : Проспект, 2017. 410 с.

2. Великий тлумачний словник сучасної української мови (з дод. і допов.) / уклад. і голов. ред. В. Т. Бусел. Київ; Ірпінь : ВТФ «Перун», 2005. 1728 с.

3. Рабінович П. М. Основи загальної теорії права та держави : навчальний посібник. Вид. 9-е, зі змінами. Львів : Край, 2007. 192 с.

4. Абрамова А. А. Эффективность механизма правового регулирования : автореф. дисс. ... канд. юрид. наук : 12.00.01. Красноярск, 2006. 24 с. 
5. Миронов А. Н. Юридическая технология подготовки нормативных правовых актов : монография. Москва : Форум, 2010. 352 с. URL: https://lawbook.online/yuridicheskoy-tehniki-osnovyi/faktoryi-vliyayuschieeffektivnost-67637.html (дата звернення: 9.10.2018).

6. Эффективность действия правовых норм / Я. И. Гилинский, Е. Н. Ловчикова, Р. С. Могилевский и др.; отв. ред. Э. А. Фомин, Л.С. Явич. Ленинград : Изд-во Ленинград. ун-та, 1977. 143 с.

7. Кархут О. Я. Ефективність механізму правового регулювання суспільних відносин в освітній сфері. Науковий часопис НПУ імені М. П. Драгоманова. Серія 18. Економіка і право. 2015. Вип. 28. С. 200-205.

8. Коновалова O. В., Андрущакевич T. В. SWOT-аналіз як основний інструмент стратегічного управління, його переваги і недоліки. Современные научные достижения. Экономические науки : материалы интернетконференции, 2010. URL: http://www.rusnauka.com/3_SND_2010/Economics/ 58123.doc.htm (дата звернення: 10.10.2018) ;

9. Шляхта О. M. SWOT-аналіз як інструмент стратегічного менеджменту підприємства. Економічний простір. 2012. № 68. С. 301-309.

10. Гуменюк О. Г. Використання SWOT-аналізу як основного інструменту стратегічного управління. Глобальні та національні проблеми економіки. 2017. Вип. 17. С. 281-285.

\section{References}

1. Kornev A. V. Sotsyolohyia prava : uchebnyk. Moskva : Prospekt, 2017. $410 \mathrm{~s}$.

2. Velykyi tlumachnyi slovnyk suchasnoi ukrainskoi movy (z dod. i dopov.) / uklad. i holov. red. V. T. Busel. Kyiv; Irpin : VTF «Perun», 2005. $1728 \mathrm{~s}$.

3. Rabinovych P. M. Osnovy zahalnoi teorii prava ta derzhavy : navchalnyi posibnyk. Vyd. 9-e, zi zminamy. Lviv : Krai, 2007. $192 \mathrm{~s}$.

4. Abramova A. A. Эffektyvnost mekhanyzma pravovoho rehulyrovanyia : avtoref. dyss. ... kand. yuryd. nauk: 12.00 .01 . Krasnoiarsk, 2006. 24 s.

5. Myronov A. N. Yurydycheskaia tekhnolohyia podhotovky normatyvnыkh pravovыkh aktov : monohrafyia. Moskva : Forum, 2010. 352 s. URL: https://lawbook.online/yuridicheskoy-tehniki-osnovyi/faktoryi-vliyayuschieeffektivnost-67637.html (data zvernennia: 9.10.2018).

6. Эffektyvnost deistvyia pravovыkh norm / Ya.Y. Hylynskyi, E.N. Lovchykova, R.S. Mohylevskyi y dr.; otv. red. Э. A. Fomyn, L.S. Yavych. Lenynhrad : Yzd-vo Lenynhrad. un-ta, 1977. 143 s.

7. Karkhut $O$. Ya. Efektyvnist mekhanizmu pravovoho rehuliuvannia suspilnykh vidnosyn v osvitnii sferi. Naukovyi chasopys NPU imeni M. P. Drahomanova. Seriia 18. Ekonomika i pravo. 2015. Vyp. 28. S. 200-205.

8. Konovalova O. V., Andrushchakevych T. V. SWOT-analiz yak osnovnyi instrument stratehichnoho upravlinnia, yoho perevahy i nedoliky. Sovremennыe nauchnыe dostyzhenyia. Эkonomycheskye nauky : materyalb ynternetkonferentsyy, 2010. URL: http://www.rusnauka.com/3_SND_2010/Economics/ 58123.doc.htm (data zvernennia: 10.10.2018);

9. Shliakhta O. M. SWOT-analiz yak instrument stratehichnoho menedzhmentu pidpryiemstva. Ekonomichnyi prostir. 2012. № 68. S. 301-309.

10. Humeniuk O. H. Vykorystannia SWOT-analizu yak osnovnoho instrumentu stratehichnoho upravlinnia. Hlobalni ta natsionalni problemy ekonomiky. 2017. Vyp. 17. S. 281-285.

\section{Почепцов Ю. В. Фактори дієвості та ефективності права як умова його функціонування}

У роботі розкрито актуальність наукового пізнання факторів ефективності і дієвості права як умови його функціонування. Встановлено філософське та наукове підгрунтя наукового дослідження факторів ефективності і дієвості права як умови його функціонування. Узагальнено наукові погляди вчених, які стосуються розуміння факторів ефективності і дієвості права як умови його функціонування. Підсумовано, що сучасний стан наукової розробки проблем факторів ефективності і дієвості права як умови його функціонування свідчить про епізодичність зазначених досліджень, оскільки наукове вивчення вказаних питань здійснювалось опосередковано через науковий аналіз інших суміжних правових явищ і процесів. Як результат, у сучасній вітчизняній юридичній науці відсутні комплексні дослідження питань факторів ефективності і дієвості права, що виступають умовами його функціонування. Автором визначено на концептуальному рівні наукознавчий потенціал факторів ефективності і дієвості права в сучасних умовах правового регулювання в Україні.

На підставі аналізу доктринальних підходів до розуміння факторів ефективності та дієвості права, визначено особливості регламентаційного впливу права на суспільні відносини, встановлено та узагальнено вказані фактори, уточнено їх характеристики.

Ключові слова: ефективність права, дія права, реалізація права, ціль права, фактори ефективності права, фактори дієвості права. 


\title{
Pocheptsov Y. V. Factors law efficiency and efficiency as a condition of its functioning
}

The questions of efficiency and effectiveness of law are some of the most urgent both in scientific and practical terms, which is not surprising given the constant development of social relations and the need to improve their normative and legal provision in a way that meets the needs of society, meets the requirements of time and international standards. At the same time, their study in the direction of finding ways to optimize the mechanisms of legal regulation should be based on a fully-fledged detection and analysis of the factors of the effectiveness and efficiency of law, which is one of the key conditions for its functioning.

Mentioned problems in the legal literature are disclosed quite episodically and inconsistently, which leads to the lack of a holistic view of the stated issues. At the same time, their scientific development is relevant, determined by the practice of law functioning, those shortcomings that are caused by the inadequacy of its effectiveness and efficiency.

The paper reveals the relevance of scientific knowledge of the factors of efficiency and effectiveness of law as conditions of its functioning. The philosophical and scientific basis of scientific research of factors of efficiency and effectiveness of law as conditions of its functioning is established. The scientific views of scientists concerning the factors of efficiency and effectiveness of law as conditions of its functioning are generalized. It is concluded that the current state of scientific development of problems of the factors of efficiency and effectiveness of law as conditions of its functioning testifies to the episodicity of these studies, since the scientific study of these issues was carried out indirectly through a scientific analysis of other related legal phenomena and processes. As a result, in today's domestic legal science, there are no comprehensive studies of the factors of the effectiveness and efficiency of law as a condition for its functioning. The author determined the conceptual level of science-learning potential of the factors of efficiency and effectiveness of law as conditions of its functioning in the current conditions of legal regulation in Ukraine.

On the basis of the analysis of doctrinal approaches to understanding the factors of efficiency and effectiveness of law, the definition of the peculiarities of the regulatory influence of law on social relations, these factors are stated and summarized, and their characteristics are specified.

The factors of efficiency and factors of the effectiveness of law can be denoted by the terms of the conditions, preconditions, factors, factors, understanding under them those circumstances that affect the ability to act and the ability to act effectively, respectively. In this case, in order to cover as many factors as possible, which should be taken into account when developing amendments to or introducing (for the first time) regulatory legal regulation of social relations, it is necessary to use as much as possible all the existing approaches to their definition in the literature, since scientists usually pay attention to a particular aspect of the law.

Key words: law effectiveness, law of action, law realization, law purpose, the factors of the effectiveness of law, the factors of the effectiveness of law.

DOI: 10.33.66.3/2524-017X-2019-10-232-236

УДК 340.1

\author{
Юрій Іванович Сверба, \\ аспірант відділу теорії держави і права \\ Інституту держави і права ім. В. М. Корецького НАН України, \\ державний експерт з доступу до правосуддя \\ Директорату з прав людини, доступу до правосуддя \\ та правової обізнаності Міністерства юстициї України
}

\section{ДОСТУП ДО ПРАВОСУДДЯ ЯК ЕЛЕМЕНТ ВЕРХОВЕНСТВА ПРАВА}

Постановка проблеми. Закріплення принципу верховенства права в Конституції України, а також його подальший нормативний розвиток в багатьох законах презюмує його основоположність в забезпеченні існування правової держави. Однак попри значну увагу до правової категорії «верховенство права» як в національній, так і в іноземній правовій доктрині, на сьогодні дискусійним все ще залишається питання його складових елементів, зокрема - доступу до правосуддя.

Аналіз останніх досліджень та публікацій. Враховуючи багатоаспектність теми доступу до правосуддя, вона була порушена в працях багатьох науковців, серед яких: I. О. Верба, В. С. Бігун, С. Ф. Демченко, Н. Ю. Сакара, А. В. Лужанський, І. В. Назаров, О. М. Овчаренко, І. С. Марочкін, П. І. Шевчук, В. М. Сидоренко тощо. Не применшуючи величезної ролі та значення наукових праць цих та багатьох інших вчених, присвячених тим чи іншим аспектам доступу до правосуддя, 